\title{
THE ROLE OF OVARIAN STEROIDS IN PLACENTAL DEVELOPMENT AND ENDOVASCULAR TROPHOBLAST MIGRATION IN THE GOLDEN HAMSTER
}

\author{
R. PIJNENBORG, W. B. ROBERTSON* AND I. BROSENS \\ Laboratory for Gynaecological Physiopathology, \\ Academisch Ziekenhuis, St Rafaël, \\ Catholic University of Leuven, Belgium
}

(Received 14th October 1974)

\begin{abstract}
Summary. Pregnant hamsters were ovariectomized on Day 7 and daily supplements of progesterone or progesterone plus oestradiol benzoate were given. Fetal development and survival was $14 \%$ and $62 \%$ respectively. Histological examination indicated that failure of labyrinthine development in the placenta resulted in failure to form an adequate number of maternal arterial spaces communicating with the base of the trophospongium to allow trophoblast migration in the related maternal spiral arteries. Progesterone was essential at all stages of gestation to sustain decidualized tissues and allow survival of a minority of fetuses. Oestradiol supplementation significantly increased fetal survival, but not to normal levels, suggesting that other oestrogens may be essential for the maintenance of normal hamster pregnancy.
\end{abstract}

\section{INTRODUCTION}

The establishment of an adequate maternal blood supply to the conceptus is an essential feature of haemochorial placentation. In the golden hamster (Mesocricetus auratus), as in women (Brosens, Robertson \& Dixon, 1967), invasion of the maternal spiral arteries by trophoblast seems to be an integral part of this process (Ward Orsini, 1954). Before trophoblast invasion begins, the walls of the spiral arteries in the placental bed of the hamster undergo changes, which we have described as a form of decidualization (Pijnenborg, Robertson \& Brosens, 1974) and which have precise time relationships with the fluctuations of peripheral plasma progesterone and oestrogen concentrations. The progesterone curve shows a significant drop between Days 9 and 11 (Lukaszewska \& Greenwald, 1970; Gutknecht, Wyngarden \& Pharriss, 1971), whereas the level of oestrogens rises progressively until Day 12 and then falls (Joshi \& Labhsetwar, 1972). It is also interesting that the decidualized walls of the spiral arteries in deciduomata in the unilaterally pregnant hamster undergo necrosis from Day 12 onwards (Pijnenborg et al., 1974).

\footnotetext{
* Present address: St George's Hospital Medical School, London.
} 
As an optimal decidual development depends upon an adequate steroid hormone supply, the role of ovarian steroids in the decidualization of the spiral arteries was investigated to see if interference with this normal process would affect the behaviour of trophoblast with regard to these vessels.

\section{MATERIALS AND METHODS}

Oestrous cycles of thirty-five virgin golden hamsters were assessed by daily vaginal smears and the females were caged individually with a male on the evening of oestrus. The day that spermatozoa were found in the vaginal smear was designated Day 1 of pregnancy.

Bilateral ovariectomy was performed on Day 7, when implantation was well established and the embryonic germ layers formed. The results were not, therefore, complicated by defects induced during this very critical period of implantation.

In twenty-eight animals, progesterone dissolved in arachis oil was given subcutaneously in a daily dose of $5 \mathrm{mg}$ from Day 6 until the day of autopsy. An attempt was thus made to eliminate the possible effect of the drop in the peripheral concentration of progesterone observed between Days 9 and 11 of normal pregnancy.

In another seven animals, the daily progesterone injections were supplemented with $1 \mu \mathrm{g}$ oestradiol benzoate. When autopsy was performed before Day 12, entire segments of uterus containing conceptuses were removed and fixed in Bouin's solution. After Day 12, any fetuses were removed and examined to determine whether they were alive or dead. The segments of uterus containing a placenta were fixed in Bouin's solution. Subsequently, all fixed tissues were embedded in paraffin wax and the blocks were cut serially; the sections were stained with haemalum and eosin.

A first series of fifteen hamsters, including the seven animals which received both progesterone and oestrogen, were killed near the end of pregnancy, i.e. on Days 14 and 15 (Table 1). In a second series, twenty animals were used to study placental development from Days 9 to 12, five animals being killed on each of the 4 days (Table 2).

\section{RESULTS}

Fetal survival in late pregnancy

The outcome of pregnancies after Day 12 when the chorioallantoic placenta should be fully established is shown in Table 1 .

Progesterone replacement alone was a poor substitute for endogenous ovarian hormones and oestrogen supplements had a beneficial effect on fetal development. Histological examination of the placental beds showed that the decidua was quite normal in all cases, irrespective of whether the fetus was alive or dead. Living fetuses were always associated with morphologically normal placentae but when the fetus was absent or dead the placenta was abnormal. In a few cases, the conceptus was represented by a mass of giant cells which were viable at about Day 8 or 9 but thereafter became progressively 
Table 1. Fetal survival rates in late pregnancy (Days 14 to 15) in ovariectomized hamsters treated with progesterone alone or with progesterone plus oestradiol benzoate

\begin{tabular}{lccccc}
\hline \multicolumn{1}{c}{ Experiment } & $\begin{array}{c}\text { No. of } \\
\text { animals }\end{array}$ & $\begin{array}{c}\text { Total no. } \\
\text { of fetuses }\end{array}$ & $\begin{array}{c}\text { No. of dead } \\
\text { fetuses }\end{array}$ & $\begin{array}{c}\text { No. of live } \\
\text { fetuses }\end{array}$ & $\begin{array}{c}\% \text { Live } \\
\text { fetuses }\end{array}$ \\
\hline $\begin{array}{l}\text { Ovariectomy } \\
\text { +progesterone }\end{array}$ & 8 & 44 & 38 & 6 & 14 \\
$\begin{array}{l}\text { Ovariectomy } \\
\text { +progesterone } \\
\text { +oestrogen }\end{array}$ & 7 & 55 & 21 & 34 & 62 \\
\hline
\end{tabular}

more necrotic. In most cases, the general structure of the fetal placenta had been formed but, while the trophospongium looked normal, the labyrinth was congested and degenerate (Pl. 1, Fig. 1). The placental abnormalities were common to both groups but the percentage of normal fetuses (and normal placentae) was much higher in the animals treated with progesterone+oestrogen than in those treated with progesterone only (Table 1).

Placental development from Days 9 to 12 in ovariectomized hamsters treated with progesterone only

Five animals were killed on each of the days under study and all their conceptuses were examined histologically. The results are summarized in Table 2.

The percentage of normal fetuses (and normal placentae) decreased from Day 9 to Day 12, when it reached $12 \%$. The placental abnormalities could be classified histologically into the following types.

Giant cell mass. This was found in the earliest conceptuses examined in this study, i.e. from Day 9 onwards. Plate 1, Fig. 2 illustrates a giant cell mass at Day 9 in which some embryonic tissue can still be seen. At later stages, most of

Table 2. State of placental development from Day 9 to Day 12 in ovariectomized hamsters given progesterone only

\begin{tabular}{|c|c|c|c|c|c|}
\hline $\begin{array}{c}\text { Day of } \\
\text { pregnancy }\end{array}$ & $\begin{array}{c}\text { No. of } \\
\text { animals }\end{array}$ & $\begin{array}{l}\text { Total no. of } \\
\text { conceptuses }\end{array}$ & State of placental development* & No. & $\%$ \\
\hline 9 & 5 & 28 & $\begin{array}{l}\text { Normal } \\
\text { Delayed fetal vascularization } \\
\text { Giant cell mass }\end{array}$ & $\begin{array}{r}16 \\
5 \\
7\end{array}$ & $\begin{array}{l}57 \\
18 \\
25\end{array}$ \\
\hline 10 & 5 & 42 & $\begin{array}{l}\text { Normal } \\
\text { Abnormal labyrinth } \\
\text { Delayed fetal vascularization } \\
\text { Giant cell mass }\end{array}$ & $\begin{array}{r}18 \\
15 \\
4 \\
5\end{array}$ & $\begin{array}{l}43 \\
35 \\
10 \\
12\end{array}$ \\
\hline 11 & 5 & 45 & $\begin{array}{l}\text { Normal } \\
\text { Abnormal labyrinth } \\
\text { Giant cell mass }\end{array}$ & $\begin{array}{r}10 \\
30 \\
5\end{array}$ & $\begin{array}{l}22 \\
67 \\
11\end{array}$ \\
\hline 12 & 5 & 32 & $\begin{array}{l}\text { Normal } \\
\text { Abnormal labyrinth } \\
\text { Giant cell mass }\end{array}$ & $\begin{array}{r}4 \\
18 \\
10\end{array}$ & $\begin{array}{l}12 \\
57 \\
31\end{array}$ \\
\hline
\end{tabular}

* See text for details.

D 
the giant cell masses became necrotic. The nuclear characteristics were the only means of determining that the degenerate cells were trophoblastic.

Delayed fetal vascularization. In a normal Day-9 conceptus, the allantoic vesicle has made contact with the chorion and ingrowth of fetal capillaries has begun (Pl. 2, Fig. 3). In several abnormal conceptuses, a lack of these fetal capillaries was observed, not only in the developing placenta but also in the allantoic vesicle itself (Pl. 2, Fig. 4). A few conceptuses on Day 10 illustrate a probable outcome of delayed fetal vascularization; the whole fetal placenta consisted only of two layers of flattened trophoblastic cells with inconspicuous fetal capillaries (Pl. 3, Fig. 5). This contrasted sharply with the normal morphology at this stage (Pl. 3, Fig. 6). Despite the abnormal placentation, the

\section{EXPLANATION OF PLATES}

Placentae and conceptuses of golden hamsters. $\mathrm{AK}=$ anastomosing knot; $\mathrm{MES}=$ mesometrium; $\mathrm{MYO}=$ myometrium; $\quad \mathrm{DEG}=$ decidua $; \quad \mathrm{TS}=$ trophospongium; $\mathrm{LAB}=$ labyrinth $; \mathrm{GC}=$ giant cell mass $; \mathrm{EG}=$ ectoplacental cone.

\section{PLATE 1}

Frg. 1. Abnormal placenta, Day 15: normal trophospongium but poorly formed, degenerate and congested labyrinth. $\times 35$.

Fig. 2. Abnormal conceptus, Day 9: a small uterine cavity is seen on the left, in the centre a trophoblast giant cell mass and to the right (arrowed) some embryonic tissue. $\times 90$.

\section{PLATE 2}

FIG. 3. Normal conceptus, Day 9: the allantoic vesicle containing fetal blood vessels has now made contact with the chorion (arrowed) which has fused with the base of the ectoplacental cone where the definitive chorioallantoic placenta will be formed. $\times 90$.

Fig. 4. Abnormal conceptus, Day 9: the allantoic vesicle contains no fetal blood vessels. $\times 150$.

\section{PLATE 3}

Fig. 5. Abnormal placenta (living fetus), Day 10: the chorioallantoic placenta is represented by only two layers of flattened trophoblast (arrowed). Above is the decidua and below the allantoic vesicle whose fetal capillaries have not penetrated the poorly developed placenta. $\times 150$.

Frg. 6. Normal placenta, Day 10: fetal vascularization of developing labyrinth. $\times 150$.

\section{PLATE 4}

FIG. 7. Abnormal placenta (living fetus), Day 10: normally developing trophospongium but inadequate 'labyrinth' (arrowed) not penetrated by fetal vessels (see Fig. 8). $\times 150$. Fic. 8. Abnormal placenta (dead fetus), Day 12: the labyrinth is grossly disorganized although there are a few fetal blood vessels (fine arrows). A very abnormal feature is the formation of syncytial trophoblast cells (heavy arrows) from labyrinthine trophoblast. $\times 150$.

\section{PLATE 5}

Fig. 9. Abnormal conceptus (dead fetus), Day 11: no trophospongium or labyrinth has developed. A few trophoblast giant cells (arrows) remain in the lumen of the spiral artery. $\times 150$.

Fig. 10. Abnormal placental bed (dead fetus), Day 15: partly necrotic spiral artery containing a few giant trophoblast cells (arrows) flattened against the vessel wall. $\times 150$.

\section{PLATE 6}

Fig. 11. Abnormal conceptus (dead fetus), Day 12: distended, congested spiral artery at junction with arterial space. $\times 90$.

Fig. 12. Abnormal conceptus (dead fetus), Day 13: three cuts (arrows) through the same spiral artery which is necrotic and ends blindly in an area of degenerate decidua. $\times 150$. 


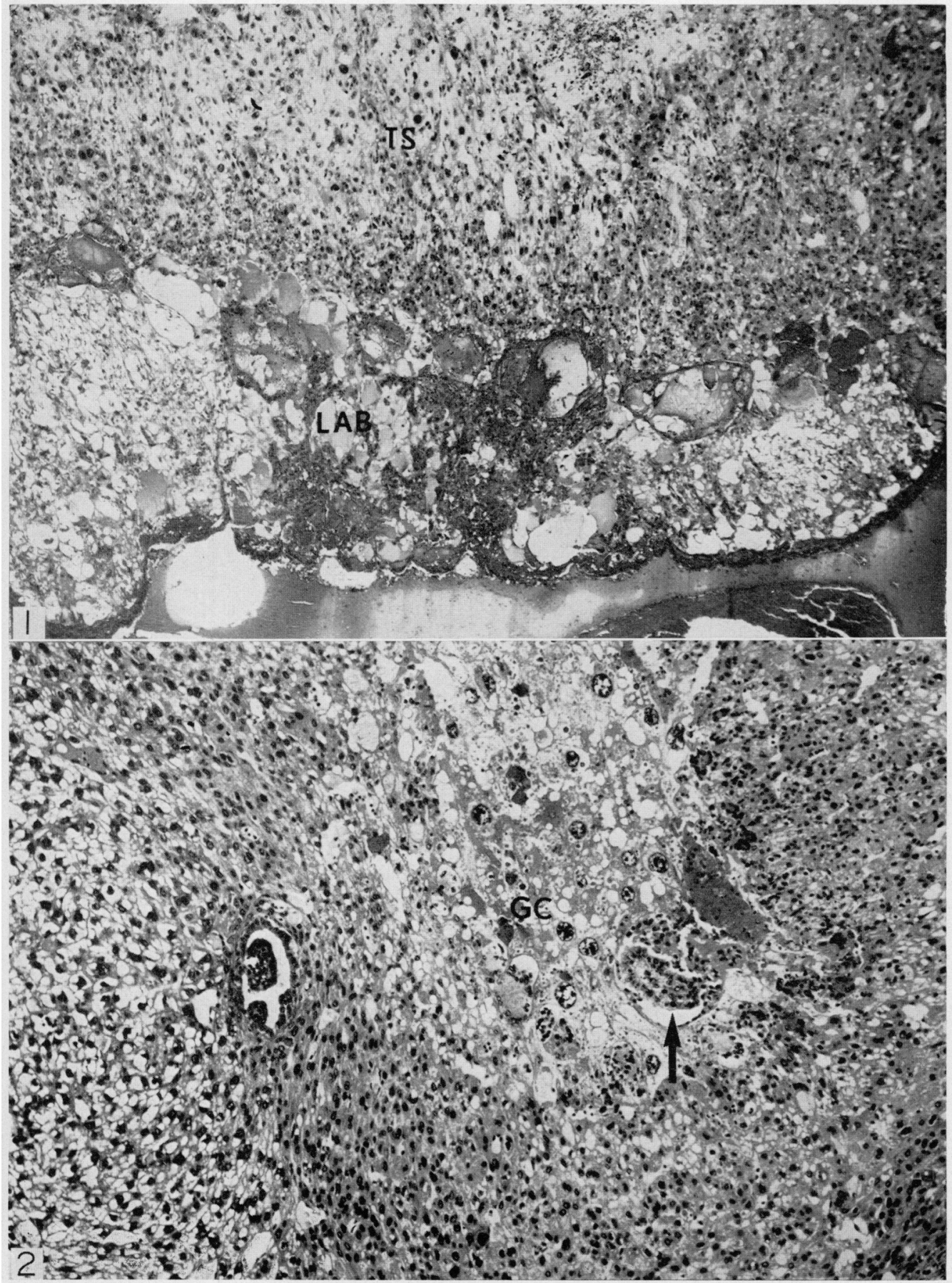


PLATE 2

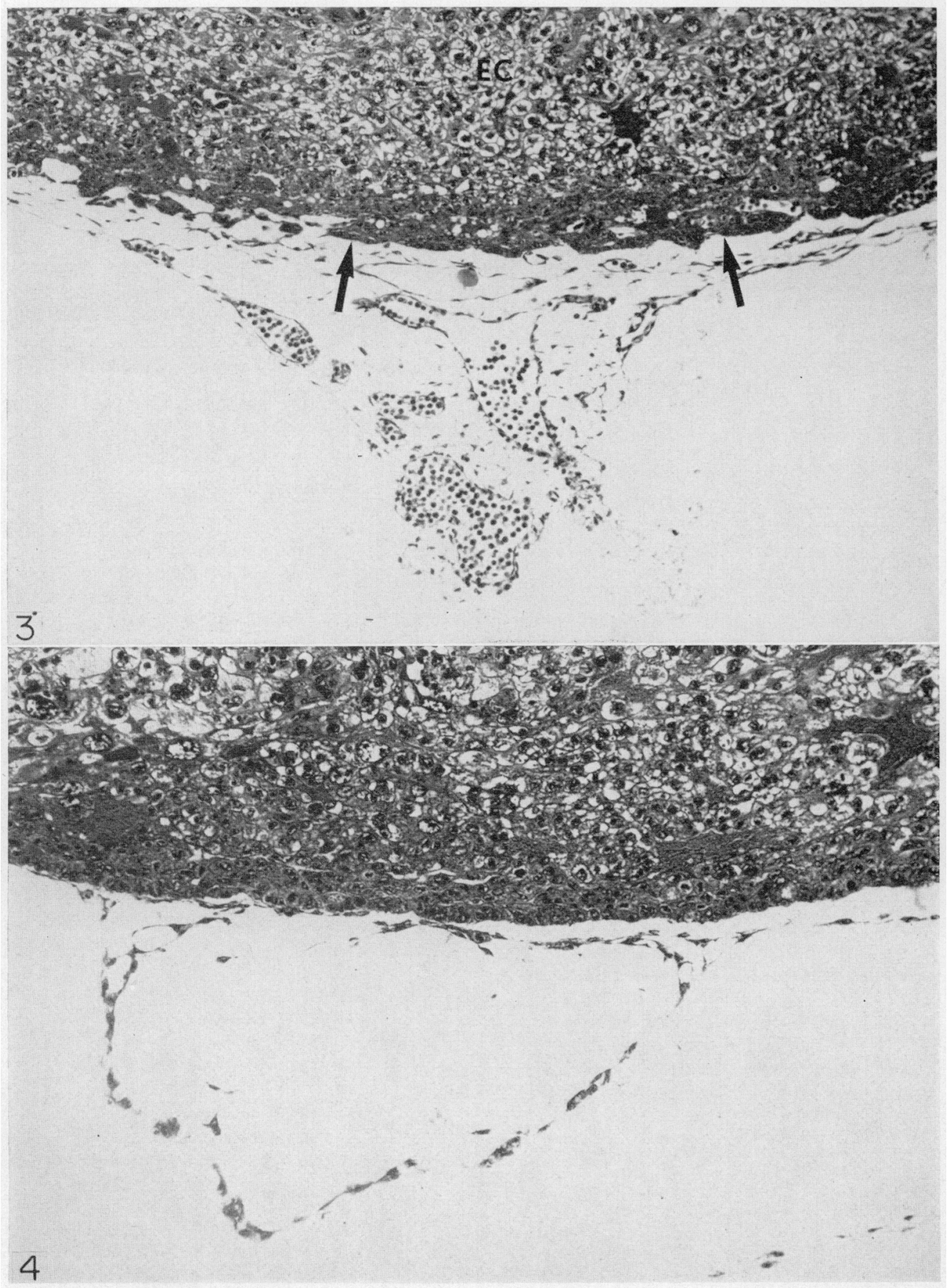




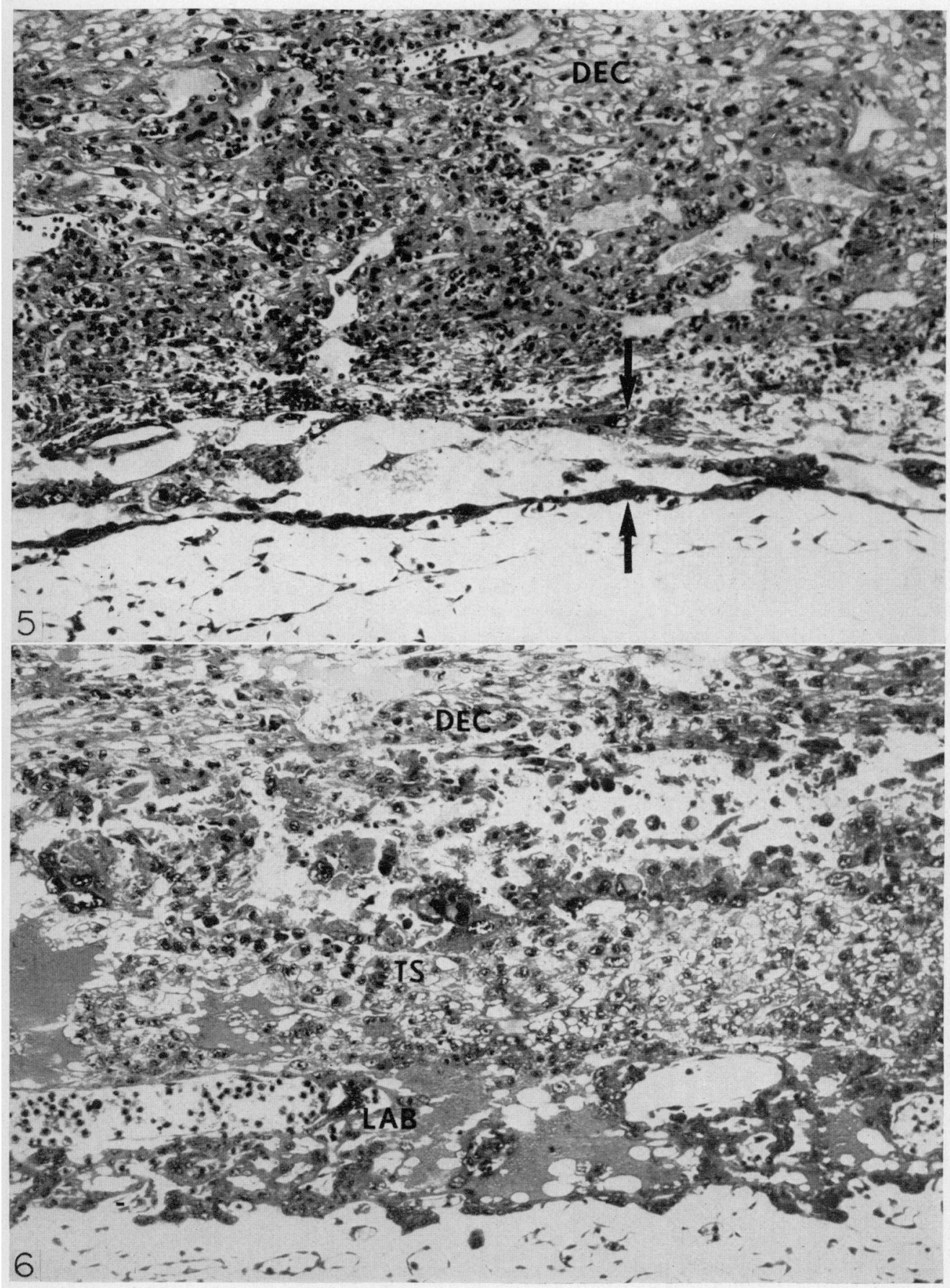


PIATE; 4



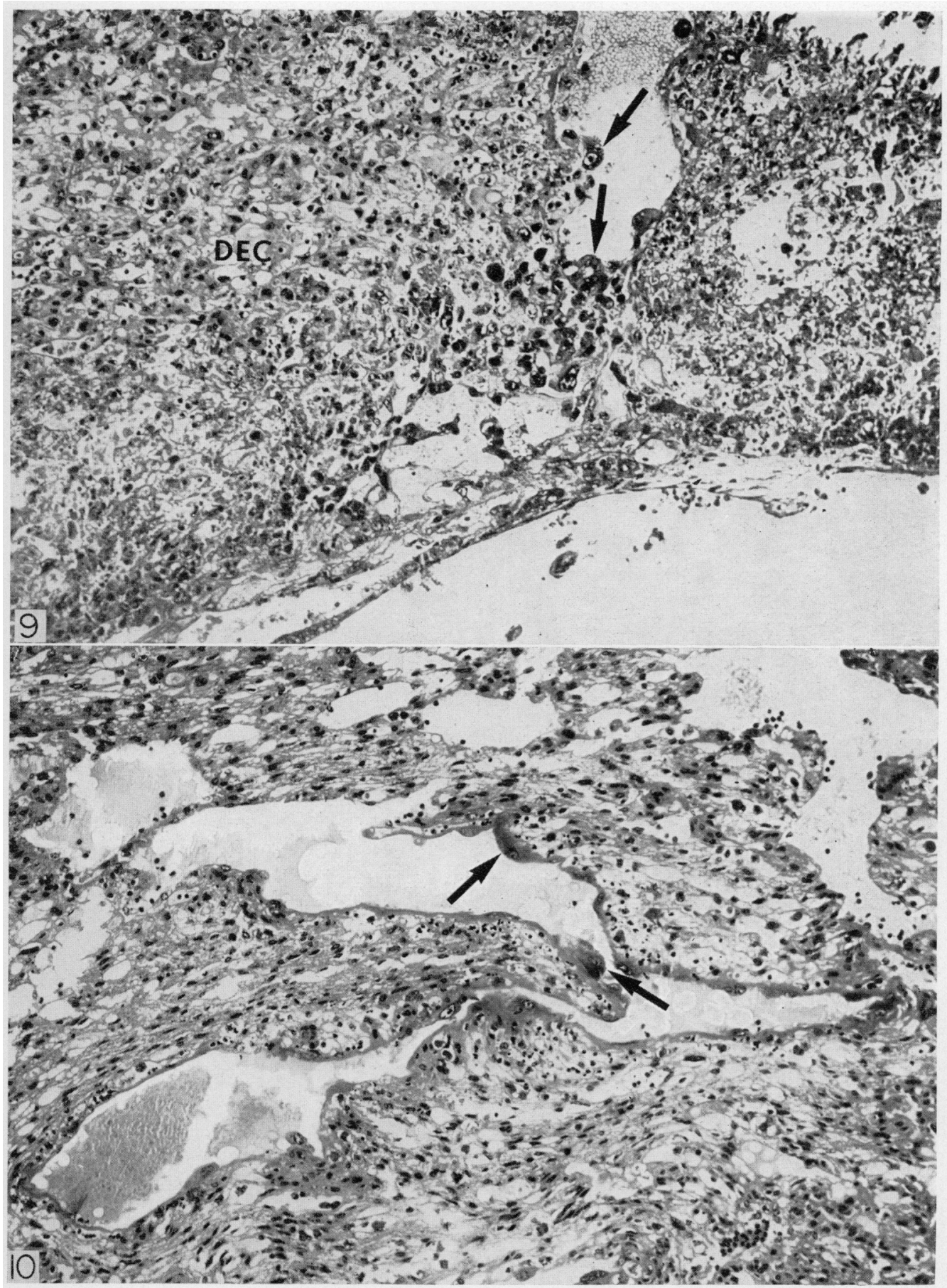




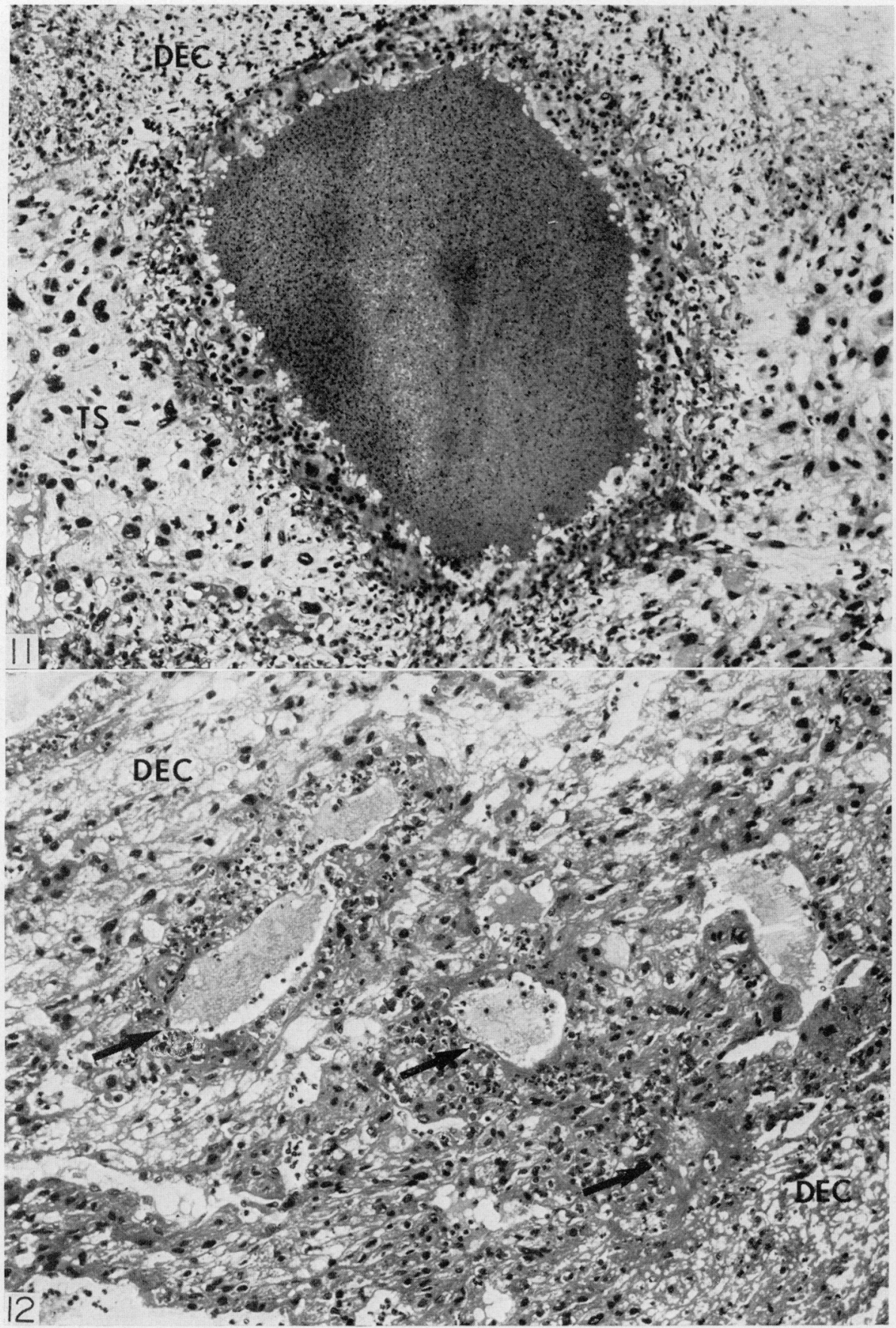


fetuses were still alive and appeared normal. No placentae showing delayed vascularization were found during Days 11 and 12.

Abnormal labyrinth development. This defect of placentation is shown in Pl. 4, Fig. 7; there was an adequate trophospongium but a hypoplastic, poorly vascularized labyrinth and the total bulk of trophoblast was much reduced. From Day 10 onwards, the number of abnormal conceptuses with inadequate labyrinth development increased (Table 2). Plate 4, Fig. 8 shows an example of such a placenta at Day 12. The fetal blood cells reaching the labyrinth appeared to fragment and lyse so that the labyrinth consisted only of a reticulum of multinuclear trophoblast. Some of the individual cells became large spherical cytoplasmic masses with the nuclei distributed around the periphery. The trophospongium, however, still appeared to be normal, and living normallooking fetuses could be associated with such placentae up to Day 11, despite pronounced congestive changes in the labyrinthine maternal blood spaces.

\section{Placental bed spiral artery development}

In normal pregnancy, before trophoblast invades the spiral arteries of the placental bed, the walls of these arteries become surrounded by a stromal sheath which then undergoes decidualization and this subsequently involves the wall of the artery itself. This process of decidualization occurred in exactly the same way, following the same time sequence, in all the experimental animals, whether the conceptus was normal or abnormal. Ovariectomy followed by steroid supplementation did not adversely effect this feature of pregnancy. With regard to endotrophoblast invasion, however, deviations from the normal were observed that could be classified into two main groups.

(a) No trophospongium present. This group included those conceptuses associated with giant cell masses and those with delayed fetal vascularization. Trophoblast might be seen in the lumina of the spiral arteries (Pl. 5, Fig. 9) as in normal pregnancy but it did not invade the wall of the vessel. These luminal trophoblastic cells were the residuum of the early invasion of maternal vessels normally observed before Day 12 , but the intramural migration, which starts exactly at Day 12 in a normal pregnancy, did not occur in these abnormal placentae. Instead, the spiral arteries underwent progressive necrosis, analogous to the changes seen in deciduomata of unilaterally pregnant hamsters. Whereas the trophoblast seen in the lumina of the terminations of the spiral arteries in early pregnancy was normally overwhelmed by secondary migrating trophoblast from Day 12 onwards, in abnormal conceptuses the luminal giant trophoblast sometimes persisted into the later stages of pregnancy, flattened against the wall of the artery, and appeared to replace maternal endothelium (Pl. 5, Fig. 10).

(b) Trophospongium present. This group comprised those conceptuses with defective labyrinth formation. In normal hamster pregnancy, two, three, or exceptionally four, main spiral arteries are invaded by trophoblast and communicate with the so-called maternal arterial spaces of the fetal placenta. In abnormal conceptuses with defective labyrinth formation, only one, or exceptionally two, spiral arteries were so involved (Text-fig. 1) and in no instance was there a failure to form at least one such communication. While trophoblast 
(a) Normal

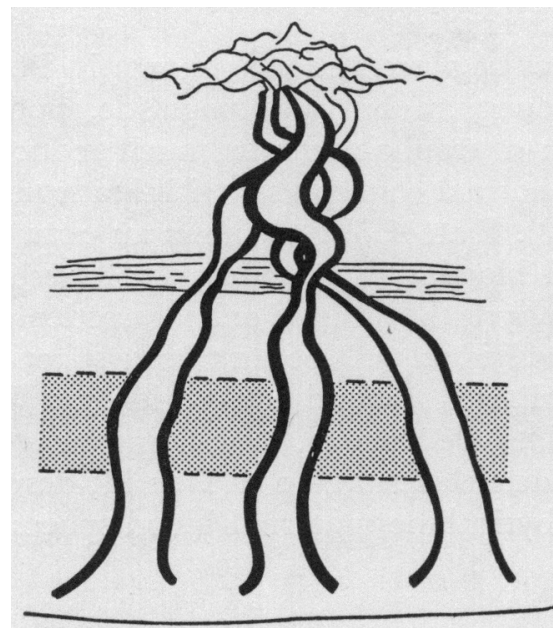

(b) Abnormal

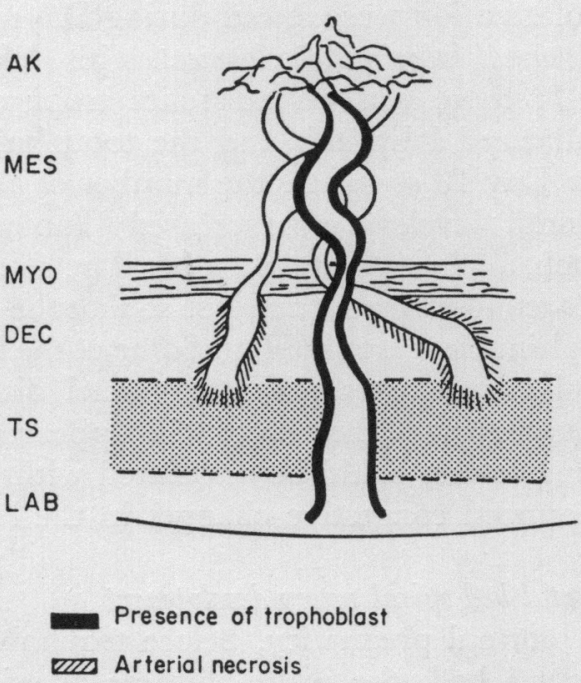

TEXT-FIG. 1. Comparison of the (a) normal and (b) abnormal placental bed in the golden hamster. In the abnormal placental bed, providing the trophospongium (TS) is present, only one central spiral artery forms a maternal arterial space to reach the labyrinth (LAB) and allow trophoblast migration from Day 12. The other spiral arteries show no trophoblast migration and undergo spontaneous necrosis. AK, anastomosing knot; MES, mesometrium; MYO, myometrium; DEG, decidua.

migration and intramural fibrinoid deposition occurred in the wall of the affected spiral artery, as in normal pregnancy, the one or two arteries involved were often distended with maternal blood (Pl. 6, Fig. 11) to a greater extent than in normal pregnancy, and may be related to the fact that the spiral arteries not invaded by trophoblast ended blindly at the junction of the decidua with the trophospongium, no maternal arterial spaces having been formed (Text-fig. 1). These spiral arteries, having been decidualized, gradually underwent necrosis (Pl. 6, Fig. 12) like the spiral arteries in deciduomata and those described above (a).

In every conceptus with a normal labyrinth and a normal fetus, all the main spiral arteries were invaded by trophoblast and showed the trophoblast migration and fibrinoid change seen in normal pregnancy.

\section{DISCUSSION}

Our experiments show that hamster pregnancy requires ovarian steroids throughout gestation to sustain fetal development and that ovariectomy followed by progesterone administration results in death of the majority of fetuses while only a minority die when progesterone is supplemented with oestradiol. Ovariectomy at any stage of pregnancy in the hamster leads to abortion (Klein, 1938) and has the same outcome in the rat during early pregnancy (Madjerek, 1971). Most investigators who studied the effect of ovariectomy on rodent pregnancies did not make histological assessments of the 
conceptuses. Recently, Clabaut (1972) has alluded to vascular disturbances, which he did not detail, associated with disappearance of the embryos following bilateral ovariectomy at Days 9 or 10 in the pregnant rat. Deanesly (1973) ovariectomized pregnant rats on Days 6 to 9 and subsequently found congestion and degeneration of decidual cells in the lateral areas of the placental bed; this effect could be overcome by administration of progesterone. Our results confirm that the maintenance of pregnancy depends upon a continuous supply of progesterone to keep the decidualized tissues intact. In the hamster, oestrogens also have a significant role in ensuring fetal survival and development (Klein, 1938; Greenwald, 1973), as they do in the rat (Linkie \& Niswender, 1973).

Ward Orsini (1963) claimed that, following ovariectomy at various stages of gestation in the hamster, progesterone supplements alone will allow implantation and development of some fetuses well into the second half of pregnancy. She concluded that her results opposed those of Klein (1938) but we would suggest that the survival and development of only a few fetuses cannot be regarded as a normal maintenance of hamster pregnancy by progesterone alone. Our results indicate that, apart from the giant cell masses found in all the stages studied and which might be the direct consequence of operative trauma, fetal death is mainly due to inadequate development of the placental labyrinth. Before Day 12, fetuses can survive with a very defective chorioallantoic placenta, as during that period the yolk sac placenta is probably more important. From Days 9 to 12, there is a drop in the proportion of normal chorioallantoic placentae to $12 \%$ (Table 2), which is comparable to the $14 \%$ survival of the fetuses at Days 14 to 15 (Table 1). Development of the labyrinth from Days 9 to 12 seems to determine fetal survival in late pregnancy, and the availability of oestrogens is probably most essential during that critical period of labyrinth development. It seems unlikely that the rise in plasma oestrogens at this time (Joshi \& Labhsetwar, 1972) and the burst of ovarian follicular growth (Greenwald, 1964) which occurs in normal hamster pregnancy at this time is coincidental.

The sharp fall in peripheral plasma progesterone levels at about the same time as the oestrogens rise requires an explanation in view of the crucial part played by progesterone in keeping decidualized tissues viable. The fall in progesterone might initiate the necrosis of decidualized spiral arteries from Day 12 onwards but, if this is so, it is surprising that, in all our experiments where high progesterone levels were maintained artificially, spiral artery necrosis proceeded in exactly the same way as in normal pregnancy. It is possible that there is no fall in the ovarian output of progesterone between Days 9 and 11 of a normal hamster pregnancy but, rather, some alteration in its metabolism at this time. Joshi, Watson \& Labhsetwar (1974) have shown that the concentration of progesterone in ovarian venous blood does not vary significantly in the hamster during pregnancy and that the calculated ovarian output of progesterone rises progressively from Day 6 to Day 10 and remains high until term. If endogenous progesterone is bound to target tissues in increased amounts so that the peripheral plasma concentration shows a drop between Days 9 and 11, then it is probable that the same is true of exogenous progesterone.

Our observation that in abnormal conceptuses there is inhibition of tropho- 
blast invasion of the requisite number of spiral arteries is not easy to explain. Billington (1971) has suggested that trophoblast will invade tissues only when there is no decidual 'barrier' or when the 'barrier' is broken down by necrosis. Although we have suggested (Pijnenborg $e t$ al., 1974) that there is a relation between vascular invasion by the trophoblast and necrosis of vessel walls which have undergone prior decidualization, we do not wish to infer that it is only the necrosis of this decidualized tissue that allows trophoblast to penetrate and migrate in spiral arteries. Our present findings with respect to invasion of spiral arteries by trophoblast are that, if no trophospongium is formed as in the giant cell masses, the second wave of trophoblast invasion and migration will not occur. If trophospongium is formed, then at least one spiral artery is invaded by Day 12. A normally developed labyrinth is always associated with trophoblastic invasion of two or three main spiral arteries on Day 12. This points to a clear-cut association between a developed labyrinth and trophoblastic invasion of spiral arteries and suggests that decidualization is only one of many factors involved. The invasion of spiral arteries by trophoblastic cells and their subsequent migration from Day 12 onwards also depends upon the prior establishment of maternal arterial spaces. These vascular channels, which in fact are lined by fetal cells, are probably formed by the haemodynamic force of the blood from the maternal spiral arteries driving through the trophospongium to supply the labyrinth. It would appear that these preformed channels provide the path for the secondary wave of migrating trophoblast and that this may be an example of rheotropic behaviour against the direction of the blood flow. Trophoblast migration may therefore be taken as an indication of the normal functioning of the spiral arteries. Those which do not form a maternal arterial space cannot make contact with the primitive trophoblast at the base of the trophospongium (Pijnenborg et al., 1974) and migration cannot occur. As with spiral arteries in deciduomata where there is no trophoblast, they therefore undergo necrosis from Day 12 onwards.

In defective placental labyrinths, there is poor ingrowth of fetal capillaries. This, in turn, may be due to the hypoxia engendered by an inadequate formation of maternal arterial spaces and an inadequate maternal blood supply, but this does not explain the failure of capillary ingrowth at an earlier stage when, normally, the maternal arterial spaces are not yet formed.

All these morphological abnormalities must be presumed to result from deprivation of the necessary steroidal hormones at certain critical stages in the development of the conceptus. Even in those animals receiving exogenous progesterone and oestradiol, the survival rate was, at best, only $62 \%$ which may indicate that other oestrogens have significant roles to play at various stages in hamster pregnancy. Exogenous oestradiol benzoate is unlikely to be a satisfactory way to replace the normal metabolic pathway of oestrogens in the intact pregnant animal.

\section{AGKNOWLEDGMENT}

This work was supported by grant 20,035 from the Fonds voor Geneeskundig Wetenschappelijk Onderzoek of the Belgian Government. 


\section{REFERENGES}

Billington, W. D. (1971) Biology of the trophoblast. Adv. Reprod. Physiol. 5, 27-66.

Brosens, I., Robertson, W. B. \& Dixon, H. G. (1967) The physiological response of the vessels of the placental bed to normal pregnancy. 7. Path. Bact. 93, 569-579.

Glabaut, M. (1972) Effets de la biovariectomie sur la jonction embryo-maternelle chez la ratte gestante avant le relais placentaire. Annls Endocr. 33, 221-230.

DeanesLy, R. (1973) Termination of early pregnancy in rats after ovariectomy is due to immediate collapse of the progesterone-dependent decidua. F. Reprod. Fert. 35, 183-186.

Greenwald, G. S. (1964) Ovarian follicular development in the pregnant hamster. Anat. Rec. 148, 605-609.

Greenwald, G. S. (1973) Further evidence for a luteotropic complex in the hamster: progesterone determinations of plasma and corpora lutea. Endocrinology, 92, 235-242.

Gutknecht, G. D., Wyngarden, L. J. \& Pharriss, B. B. (1971) The effect of prostaglandin F $_{2 \alpha}$ on ovarian and plasma progesterone levels in the pregnant hamster. Proc. Soc. exp. Biol. Med. 136, 1151-1157.

Joshi, H. S. \& LABHSETwAR, A. P. (1972) The pattern of ovarian secretion of oestradiol and oestrone during pregnancy and the post-partum period in the hamster. F. Reprod. Fert. 31, 299-302.

Joshi, H. S., WATSON, D. J. \& LABHSETwAR, A. P. (1974) Relationship between progesterone secretion and peripheral plasma levels of LH during pregnancy and postpartum period in hamsters. Biol. Reprod. 10, 39-46.

KLEIN, M. (1938) Relation between the uterus and the ovaries in the pregnant hamster. Proc. R. Soc. B, 125, 348-364.

LinkIE, D. M. \& Niswender, G. D. (1973) Gharacterization of rat placental luteotropin. Physiological and physicochemical properties. Biol. Reprod. 8, 48-57.

Lukaszewska, J. H. \& Greenwald, G. S. (1970) Progesterone levels in the cyclic and pregnant hamster. Endocrinology, 86, 1-9.

MAdjerex, Z. S. (1971) Progesterone and the maintenance of pregnancy. In Pharmacology of the Endocrine System and Related Drugs: Progesterone, Progestational Drugs and Antifertility Agents, Vol. I, pp. 291-318. Ed. M. Tausk. Pergamon Press, Oxford.

Pijnenborg, R., Robertson, W. B. \& Brosens, I. (1974) The arterial migration of trophoblast in the uterus of the golden hamster, Mesocricetus auratus. F. Reprod. Fert. 40, 269-280.

WARD ORsinI, M. (1954) The trophoblastic giant-cells and endovascular cells, associated with pregnancy in the hamster, Cricetus auratus. Am. F. Anat. 94, 273-330.

WARD ORSINI, M. (1963) Morphological evidence of the intrauterine career of the ovum. In Delayed Implantation, pp. 155-169. Ed. A. C. Enders. University of Ghicago Press. 